\title{
Effect of NP Fertilizer Rates and Plant Population Density on Late Maturing Maize Variety at Jimma and Buno-Bedele Zone, Southwestern Ethiopia
}

\author{
Sisay Gurmu* Muhidin Biya EshetuYadete \\ Jimma Agricultural Research Center, P. O. Box 192, Jimma, Ethiopia
}

\begin{abstract}
Maize is among the leading cereals in production globally and an important potential food security crop in Ethiopia. However, its productivity is very low mainly due to low soil fertility and plant stands per area. Therefore, a field experiment was conducted to determine the effect of NP fertilizer and plant density at Jimma and BunoBedele Zone, Southwestern Ethiopia during 2016-2018 main cropping seasons. The experiment had four nitrogen and phosphorus rates $\left(\mathrm{P}_{2} \mathrm{O}_{5}\right) ; 69 / 52,92 / 69,115 / 86$ and 138/104 $\mathrm{kg} \mathrm{ha}^{-1}$; blended NPSZnB fertilizer $\left(150 \mathrm{~kg} \mathrm{ha}^{-1}+140\right.$ $\mathrm{kg} \mathrm{ha}^{-1}$ urea top dressed) and four plant density; 44,444, 53,333, 66,666, and 88,888. Each treatment was assigned to each plot in split plot design in which fertilizer assigned to sub plot and plant density assigned to main plot.Data on the yield and yield components were subjected to ANOVA using SAS version 9.3. The highest grain yield $7566.2 \mathrm{~kg} \mathrm{ha}^{-1}$ and above ground biomass 15.07 ton ha-1 were recorded from 138/104 N/ $\mathrm{P}_{2} \mathrm{O}_{5}$ fertilizer followed by grain yield $7182 \mathrm{~kg} \mathrm{ha}^{-1}$ and above ground biomass 19.94 ton $\mathrm{ha}^{-1}$ by 66,666 plant ha- $\mathrm{h}^{-1}$. The highest net benefit $35,050.18$ and 37,220.6 ETB were obtained from 138/104 kg ha-1 $\mathrm{N}^{-} \mathrm{P}_{2} \mathrm{O}_{5}$ and plant density of 53,333 $\left(75^{*} 25 \mathrm{~cm}\right)$. Therefore, it is advisable for farmers in the study area and adjacent woredas' with similar agro-ecologies, a plant density of 53,333 plant ha- ${ }^{-1}\left(75 \times 25 \mathrm{~cm}\right.$ a plant hill ${ }^{-1}$ or $75 \times 50 \mathrm{~cm}$ two plants hill $\left.{ }^{-1}\right)$ in complement with $\mathrm{N} / \mathrm{P}_{2} \mathrm{O}_{5}$ fertilizer rate of $92 / 69 \mathrm{~kg} \mathrm{ha}^{-1}$ can be recommended.
\end{abstract}

Keywords: Grain yield, inorganic fertilizer and plant population

DOI: $10.7176 / \mathrm{JEES} / 10-6-01$

Publication date: June $30^{\text {th }} 2020$

\section{Introduction}

Like any other tropical countries, most cropping systems in Ethiopia are traditional and crop bases are complex, vary across agro-ecologies and diverse according to cultural food needs of resource-poor farmers. Maize is commonly planted in rows of varying spaces; less effort has been made to study the optimum densities to maximize its productivity in different agro-ecologies of Ethiopia. Summaries of earlier results from different studies on maize plant population densities indicate that better yields were obtained at planting density in range of 4-7 plants $\mathrm{m}^{-2}$ $\left(40,000-70,000\right.$ plants ha $\left.{ }^{-1}\right)$ (Tenaw et al., 1993). Later studies confirmed that at 5-7 plants $/ \mathrm{m}^{2}$ medium to late maize maturity groups gave maximum yields in humid regions, while early maturity groups produced maximum yields at higher densities in both humid and moisture stress areas (Tenaw et al., 2002). It is being observed that lately innovated medium and early maize varieties in humid lowlands and low moisture stress area found to be varied in structure and leaf arrangements from known normal maize varieties. These variations in morphology may lead to different planting density to attain maximum yield potentials.

Plant population density have a significant impact on growth and yield of crops, including maize, a popular C4 cereal crop (Cox, 1996). Therefore, understanding how plants regulate their growth in response to plant population densities has problems, such as determination of optimal sowing density (Cox, 1996). Increasing plant populations could lead to increase yields under optimal climatic and management conditions due to greater number of smaller cobs per unit area (Bavec and Bavec,2002).

Plant population is the prime factor for getting maximum yield which is decided by inter and intra row spacing of crops. Decreasing the distance between neighbor rows at any particular plant population has several potential advantages. First, it reduces competition among plants within rows for light, water and nutrients due to a more equidistant plant arrangement (Porter et al., 1997). The more favorable planting pattern provided by closer rows enhances maize growth rate early in the season (Bullock et al., 1988), leading to a better interception of sun light, a higher radiation use efficiency and a greater grain yield (Westgate et al., 1997).

Secondly ,the maximization of light interception from early canopy closure also reduces transmittance through the canopy(McLachlan et al., 1993). The smaller amount of sunlight striking the ground decreases the potential for weed interference, especially for shade intolerant species(Johnson et al.,1998). Thirdly, the quicker shading of soil water being lost by evaporation (Karlen and Camp,1985).This is especially important under favorable soil surface moisture conditions because it allows maize plants to maximize photosynthesis and the proportion of water that is used growth processes rather than evaporated from the soil (Lauer,1994). Furthermore earlier crop cover provided by smaller row width is instrumental to enhance soil protection, diminishing water runoff and soil erosion (Sangoi et al.,1998). The nutrient use efficiency can be improved with the use of optimum 
plant population (Srikanth et al.,2009).

However, according to Duncan (1984) plant population above critical density has negative effect on yield per plant due to the effects of inter plant competition for light, water, nutrient and other potential yield limiting environmental factors. Most soils contain an abundance of elements essential for the plants development, but majority of these elements are rarely available for plant use. Nutrient depletion and soil degradation have become serious threat to agricultural productivity in Ethiopia. These soils suffered multi-nutrient deficiencies so that, application of mineral fertilizers has become mandatory to increase crop yields in such soils (Adeniyan and Ojeniyi, 2005).

According to Srikanth et al. (2009) among the plant nutrients, primary nutrients such as nitrogen and phosphorus play a crucial role in determining the growth and yield. The nutrient use efficiency can be proved with the use of hybrids, optimum plant population and application of chemical fertilizer coinciding with peak need by the crop. Hence, the experiment was done with the objective of evaluating the response of maize hybrid BH661 to different rates of NP fertilizer and plant population density; and to identify the economic optimum rate of NP fertilizer for production of maize.

\section{Materials and Methods}

\subsection{Description of the Study Area}

Field farm experiment was conducted in two sites of Jimma Zone (Kersa and Omonada woreda) and Buno-Bedele Zone (Banshure kebele), Southwestern Ethiopia during cropping season of 2016-2018. The Kersa site was located on latitude $7^{\circ} 42^{\prime} \mathrm{N}$ and longitude $36^{\circ} 59^{\prime} \mathrm{E}$ and laid at an altitude of $1753 \mathrm{~m}$.a.s.l. The average minimum and maximum temperature is $6^{\circ} \mathrm{C}$ and $25.5^{\circ} \mathrm{C}$ respectively and reliably receives good rains $1712 \mathrm{~mm}$ per annum during cropping season. Whereas, Omonada site was located on latitude $7^{\circ} 37^{\prime} \mathrm{N}$ and longitude $37^{\circ} 14^{\prime} \mathrm{E}$ and laid at an altitude of 1753 m.a.s.l. The average minimum and maximum temperature is $6^{\circ} \mathrm{C}$ and $25^{\circ} \mathrm{C}$ respectively and reliably receives good rains $1446 \mathrm{~mm}$ per annum cropping season. The Bedele site was located on latitude $8^{\circ} 32^{\prime} \mathrm{N}$ and longitude $36^{\circ} 22^{\prime} \mathrm{E}$ and laid at an altitude of $1753 \mathrm{~m}$.a.s.l. The average minimum and maximum temperature is $6^{\circ} \mathrm{C}$ and $24.5^{\circ} \mathrm{C}$ respectively and reliably receives good rains $1712 \mathrm{~mm}$ per annum cropping season. The farming system of the study site is coffee and cereal crops dominated with coffee, maize, teff and sorghum also has warm and cold climate, also convenient topography is very suitable for all agricultural practices. It was situated in the tepid to cool humid-mid highlands of southwestern Ethiopia. The soil type of the experimental area was Eutricnitisols (reddish brown).

\subsection{Soil Physico-chemical Properties}

The soil of the experimental field was characterized by selected physico-chemical properties before the application of the treatments (Table 1). The average soil $\mathrm{pH}$ of the trial sites ranges from 4.96 to 5.00, which was strongly acidic (Batjes, 1995) and ideal for the production of most field crops. The $\mathrm{pH}$ of the soil affects maize growth by suppressing the root development and reducing availability of macronutrients to plants especially phosphorus (Brady and Weil, 2008). The soil total $\mathrm{N}$ ranges from 0.19 to $0.20 \%$ and OC from 2.02 to $2.20 \%$ were found medium rate for crop growth and development for both nutrients (Berhanu, 1980). The Bray II extractable available P for Kersa woreda was $3.72 \mathrm{mg} \mathrm{kg}^{-1}$, which is below the critical level $\left(8 \mathrm{mg} \mathrm{kg}^{-1}\right)$ for most crop plants whereas, Omonada and Bedele sites were ranges from 8.96 to $12.32 \mathrm{mg} \mathrm{kg}^{-1}$ which is medium to high in content as described by Tekalign and Haque (1991).

Table 1 Selected physico-chemical properties of the soil of the experimental sites before planting

\begin{tabular}{lrcc}
\hline Soil characters & \multicolumn{3}{c}{ Location } \\
\cline { 2 - 4 } & Kersa & Omonada & Bedele \\
\hline $\mathrm{pH}(1: 2.5)$ & 4.96 & 5.15 & 5.00 \\
$\mathrm{Av} \mathrm{P}\left(\mathrm{mg} \mathrm{kg}^{-1}\right)$ & 3.72 & 12.32 & 8.96 \\
$\mathrm{TN}(\%)$ & 0.20 & 0.19 & 0.20 \\
$\mathrm{OC}(\%)$ & 2.12 & 2.02 & 2.20 \\
$\mathrm{OM}(\%)$ & 3.65 & 3.47 & 3.78 \\
$\mathrm{C}: \mathrm{N}$ ratio & 10.61 & 11.05 & 11.40 \\
\hline
\end{tabular}

Where $\mathrm{pH}=$ hydrogen power, $\mathrm{OC}=$ Organic carbon, $\mathrm{TN}=$ Total Nitrogen, Av. $\mathrm{P}=$ Available Phosphorous, $\mathrm{OM}=$ Organic Matter. Values are the means of duplicated samples.

\subsection{Description of the experimental materials}

Hybrid maize variety BH661 was used in the present study. It is the most promising variety released by Bako Agricultural Research Centre and adapted well to the agro-ecologies of Jimma and Buno Bedele areas.

\subsection{Experimental treatments and procedures}

The experimental field was ploughed and prepared following the conventional tillage practice before planting at 
all experimental locations. The land was leveled using manual power before the field layout was made. The maize was planted during 18 up to 22 May at different locations and years. Two maize seeds were planted per hill and then thinned to one plant per hill after good establishment of seedlings so as to maintain a single healthy plant per hill. This experiment include twenty treatments in three replications which were four nitrogen and phosphorus rates $\left(\mathrm{P}_{2} \mathrm{O}_{5}\right) ; 69 / 52,92 / 69,115 / 86,138 / 104 \mathrm{~kg} \mathrm{ha}^{-1}$ and blended NPSZnB fertilizer $\left(150 \mathrm{kgha}^{-1}+140 \mathrm{~kg} \mathrm{ha}^{-1} \mathrm{urea}\right.$ top dressed) and four plant population density; 44,444, 53,333, 66,666, and 88,888 plants per hectare. The plot size $22.95 \mathrm{~m}^{2}(4.5 \mathrm{~m} \times 5.1 \mathrm{~m})$ was used for each treatment. Each factor within a replication was randomly arranged to plant population densities in main plot and fertilizer rates in subplot.

Nitrogen fertilizer rates were applied during planting and other half at the knee height growth stage to increase the nitrogen use efficiency. All other agronomic practices were applied uniformly to all experimental plots in the study area.

\subsection{Data collected}

2.5.1 Plant height $(\mathbf{c m})$ : it was measured at ground level to terminal stem using measuring stick at the point where the tassel starts branching from six randomly selected plants.

2.5.2 Number of ear per plant: it was obtained by counting total number of ears in each plot and divided to total number of plant stand harvested.

2.5.3 Grain yield $\left(\mathrm{kg} \mathrm{ha}^{-1}\right)$ : grain yield per plot was recorded using electronic balance and then adjusted to $12.5 \%$ moisture and converted to hectare basis.

2.5.4 Above ground biomass $\left(\mathrm{kg} \mathrm{ha}^{-1}\right)$ : all above ground biomass was harvested from net plot and weighted, ears were removed and weighted separately, six plants were selected, chopped and oven dried till get uniform weight. 2.5.5. Lodging percent: it was obtained by counting the total number of stalk and root lodging in each plot and divided to the total number of plant stand at harvesting.

2.5.6 Harvest index: was calculated as the ratio of grain yield to above ground biomass yield on dry weight basis (Donald, 1962). HI $(\%)=\frac{\text { Economic yield }(\mathrm{kg} / \mathrm{ha})}{\text { Total biological yield }(\mathrm{kg} / \mathrm{ha})} \times 100$

\subsection{Data analysis}

Analysis of variance (ANOVA) for all collected data was computed using SAS version 9.3 statistical software. Whenever the ANOVA results showed the significant differences between sources of variation, the means were compared using least significant difference. The homogeneity test was done as suggested by Gomez and Gomez, (1984).

\subsection{Partial budget analysis}

Partial budget analysis was performed to investigate the economic feasibility of the treatments and assess the costs and benefits associated with different treatments of chemical fertilizers and plant population density of the seed rates. The partial budget technique as described by CIMMYT (1988) was applied. The partial budget analysis was done using the prevailing market prices for inputs at planting and for outputs at the time the crop was harvested. All costs and benefits were calculated on hectare basis in Ethiopian Birr (ETB). The inputs and/or concepts used in the partial budget analysis were the mean grain yield of each treatment, the gross field benefit (GFB) ha ${ }^{-1}$ (the product of field price and the mean yield for each treatment), the field price of chemical fertilizers and $\mathrm{urea}_{\mathrm{kg}}{ }^{-1}$ (the nutrient cost plus the cost of transportation from the point of sale to the farm), cost of labor spent on seed purchase and planting, the total costs that varied (TVC) which included the sum of field costs of fertilizers and their application, and seed purchase and planting.

The net benefit (NB) was calculated as the difference between the GFB and the TVC. The marginal rate of return (MRR \%) were also calculated. To obtain an estimate of these returns, the MRR (\%) was calculated as changes in NB divided by changes in cost. Thus, a minimum acceptable MRR of $100 \%$ was used indicating, for every one ETB expended there is a return of one ETB for a given variable input (CIMMYT, 1988), which is suggested to be realistic. This enables' to make farmer recommendations from marginal analysis. The dominance analysis procedure as detailed in CIMMYT (1988) was used to select potentially profitable treatments from the range that was tested. Sensitivity analysis for different interventions was also carried out to test the recommendation made for its ability to withstand price changes. Sensitivity analysis simply implied redoing marginal analysis with the alternative prices. Through sensitivity analysis, maximum acceptable field price of an input was calculated with the minimum rate of return as described by Shah et al. (2009).

\section{Results and Discussions}

The effect of different rates of NP fertilizer and plant population density on yield and yield related parameters and cost benefit analysis were presented and discussed as follows. It has been observed that late maturing maize variety like BH661 vary in structure and leaf arrangements from other medium maturing/early maturing maize varieties. 
These variations in morphology may lead to different planting density to reach the maximum yield potentials. The combined analysis effects of NP fertilizer rates and plant population density over locations and seasons didn't show significant $(\mathrm{P}>0.05)$ interaction effect on plant height, ears per plant, lodging percent, grain yield, aboveground biomass and HI. Plant height was not significantly influenced by either NP fertilizer or plant population density, where as ears per plant, harvest index, grain yield and above ground biomass were highly significantly $(\mathrm{P}<0.01)$ influenced by NP fertilizer rates and plant population density. However, lodging percentage was not significantly $(\mathrm{P}>0.05)$ affected by NP fertilizer rates, but it was highly significantly $(\mathrm{P}<0.01)$ affected by plant population density (Table 2).

\subsection{Effect of NP Fertilizer and Plant Population Density on Growth Parameters 3.1.1 Plant height}

The interaction effect of NP fertilizer and plant population density, and the main effect of NP fertilizer and plant population density were not significantly $(\mathrm{P}>0.05)$ affect plant height of the crop (Table 2$)$.

\subsection{Effect of NP Fertilizer and Plant Population Density on Yield and Yield Related Parameters 3.2.1 Numbers of Ears per plant}

Over season and location mean indicated that the maximum number of ears per plant (0.97) was recorded from $138 / 104 \mathrm{~kg} \mathrm{ha}^{-1} \mathrm{~N} / \mathrm{P}_{2} \mathrm{O}_{5}$ fertilizer. But its effect was statistically at par with $69 / 52,92 / 69$ and $115 / 86 \mathrm{~kg} \mathrm{ha} \mathrm{N}^{-1} \mathrm{~N} / \mathrm{P}_{2} \mathrm{O}_{5}$ fertilizer, while the minimum number of ears per plant (0.90) was recorded from $150 \mathrm{~kg} \mathrm{ha}^{-1}$ blended NPSZnB $+140 \mathrm{~kg} \mathrm{ha}^{-1}$ urea top dressed (Table 2). Application of 138/104 kg ha-1 $\mathrm{N}^{-} \mathrm{P}_{2} \mathrm{O}_{5}$ fertilizer increased number of ears per plant by $5.6 \%$ over blended NPSZnB fertilizer. These results were in line with the result of Singh and Nepalia (2009) who reported that application of higher dose of chemical fertilizer improved the number of cobs plant ${ }^{-1}$ in QPM hybrid over the lower nutrient application.

Regarding the effect of plant population density on number of ear per plant the data show that, the maximum number of ear per plant (1.06) was recorded by 44,444 plants ha ${ }^{-1}\left(75^{*} 30 \mathrm{~cm}\right)$, while the minimum number of ear per plant $(0.81)$ was recorded by 88,888 plants $\mathrm{ha}^{-1}\left(75^{*} 15 \mathrm{~cm}\right)$ (Table 2$)$. The plant population density at 44,444 plants ha ${ }^{-1}$ increased $30.9 \%$ number of ears per plant over 88,888 plants ha $^{-1}$. The results indicate as plant population density increased the number of ear per plant decreased. At low plant population density, number of plants limited the yield, while at high plant population density number of barren plants limited yield as well. This might be due to efficiently use of the crop to the nutrient applied per plant stand, and this which in turn had increased the nutrient availability for vigorous plant growth thus might have increased the number of ears plant ${ }^{-1}$. These findings are in agreement with Hashemi-Dezfouli and Herbert (1992) who reported a significant higher number of ears per plant at lower plant density as compared to higher plant density.

\subsubsection{Lodging percent}

Maize variety BH-661 was sensitive to lodging, as its plant height is goes higher up to $291 \mathrm{~cm}$ as indicated in table 2 below. Stalk lodging represents one of the most serious constraints to the use of high plant densities in maize BH-661 variety. The lodging percent was not significantly $(P>0.05)$ affected by interaction of NP fertilizer and plant population density and the main effect of NP fertilizer but significantly $(\mathrm{P}<0.05)$ affected by plant population density. Numerically, the highest lodging percent (57.6\%) was recorded from the higher plant population density of 88,888 plants ha ${ }^{-1}\left(75^{*} 15 \mathrm{~cm}\right)$ while, the minimum lodging percent $(46.9 \%)$ was recorded from 44,444 plants $\mathrm{ha}^{-1}\left(75^{*} 30 \mathrm{~cm}\right)$ (Table 2$)$. The lodging percent decreased $18.6 \%$ by plant population density at 44,444 plants $^{-1}$ over 88,888 plants $\mathrm{ha}^{-1}$. The obtained results indicate that as the plant population density increased the lodging percent also increased and vice versa. As the plant density increases the internodes become thinner, making the plant more prone to stalk lodging (Song et al., 2016). The stored carbohydrates in the maize stalks were transported to grains and weakened the basal internodes, thus reducing the bending quality and providing an ease of lodging (Xue et al., 2016); this is because the basal internodes act as a lever for holding the plants upright (Yuan et al., 2002). These results were in line with the result of Gou et al., (2010), who reported more observed lodging at high plant population density as compared with lower densities.

\subsubsection{Grain yield}

As regards the effect of different ratios of phosphorus and nitrogen fertilizer ratios on grain yield the obtained results indicate that the highest grain yield $7566.2 \mathrm{~kg} \mathrm{ha}^{-1}$ was recorded from 138/104 N/ $\mathrm{P}_{2} \mathrm{O}_{5}$ fertilizer rate which was statically at par with $115 / 86 \mathrm{~N} / \mathrm{P}_{2} \mathrm{O}_{5}$ fertilizer rate. On the other hand, the lowest grain yield $6223.9 \mathrm{~kg} \mathrm{ha}^{-1} \mathrm{was}$ recorded from blended NPSZnB fertilizer $150 \mathrm{~kg} \mathrm{ha}^{-1}+140 \mathrm{~kg} \mathrm{ha}^{-1}$ urea top dressed (Table 2). Higher grain yield percentage $17.8 \%$ obtained by $115 / 86 \mathrm{~N} / \mathrm{P}_{2} \mathrm{O}_{5}$ as compared to the blended NPSZnB fertilizer. Such reduction of grain yield might be due to nutritional imbalance and deficiency of certain important plant growth elements at various important growth stages and also due to reduced leaf area development resulting in lesser radiation interception and, consequently, low efficiency in the conversion of solar radiation. The higher doses of chemical fertilizers increased grain yield as nutrients are the main driving force to produce high yield of maize (Nivong et al., 2007). 
Concerning the response of grain yield to plant population density the presented data show that the highest grain yield $7182 \mathrm{~kg} \mathrm{ha}^{-1}$ was recorded from $75^{*} 20 \mathrm{~cm}\left(66,666\right.$ plant ha $\left.{ }^{-1}\right)$ which was not statistically significant differ from 88,888 and 53,333 plant ha ${ }^{-1}$. While, the lowest grain yield $6542.4 \mathrm{~kg} \mathrm{ha}^{-1}$ was recorded from the lowest plant population density of 44,444 plants ha- (Table 2). The data also showed that by planting 53,333 plants ha $^{-1}$ there was $9.1 \%$ grain yield increase over plant population density of 44,444 plant ha ${ }^{-1}$. Such effect may be related to the increase of plant per meter square area and subsequently increase number of cob harvested. Thus, balanced growth and development of plants need optimum plant population density because optimum density enables plants efficient utilization of available nutrients, soil water and better light interception coupled with other growth influencing factors. These finding was in agreement with those obtained by Farnham (2001) who reported that maize grain yield increased as plant density increased from 59,000 to 89,000 plant ha ${ }^{-1}$.

Table 2 Over season and location main effect of fertilizer rate and plant population density on yield and yield components of maize at Jimma and Buno-Bedele zone during 2016-2018 cropping season

\begin{tabular}{|c|c|c|c|c|c|c|}
\hline \multirow[b]{2}{*}{$\begin{array}{l}\mathrm{N} / \mathrm{P}_{2} \mathrm{O}_{5} \\
\left(\mathrm{Kg} \mathrm{ha}^{-1}\right)\end{array}$} & \multicolumn{5}{|c|}{ Over location and year } & \multirow[b]{2}{*}{ HI } \\
\hline & $\begin{array}{c}\text { Plant } \\
\text { height }(\mathrm{cm})\end{array}$ & EPP & Lodging $\%$ & $\begin{array}{l}\text { Grain yield } \\
\left(\mathrm{kg} \mathrm{ha}^{-1}\right)\end{array}$ & $\mathrm{AGB}\left(\right.$ ton $\left.\mathrm{ha}^{-1}\right)$ & \\
\hline $69 / 52$ & 285.2 & $0.94 \mathrm{a}$ & 53.8 & $6636.6 \mathrm{c}$ & $13.70 \mathrm{c}$ & $0.49 b$ \\
\hline $92 / 69$ & 286.7 & $0.93 \mathrm{ab}$ & 52.7 & $7020.7 b$ & $14.22 \mathrm{bc}$ & $0.50 \mathrm{ab}$ \\
\hline $115 / 86$ & 287.3 & $0.95 \mathrm{a}$ & 51.2 & 7331.3ab & $14.80 \mathrm{ab}$ & $0.50 \mathrm{ab}$ \\
\hline $138 / 104$ & 290.9 & $0.97 \mathrm{a}$ & 52.6 & $7566.2 \mathrm{a}$ & $15.07 \mathrm{a}$ & $0.51 \mathrm{a}$ \\
\hline $\begin{array}{l}\text { NPSZnB }(150+140 \mathrm{~kg} \\
\left.\text { ha }^{-1} \text { urea top dressed }\right)\end{array}$ & 285.4 & $0.90 \mathrm{~b}$ & 52.8 & $6223.9 d$ & $14.75 \mathrm{ab}$ & $0.42 \mathrm{c}$ \\
\hline $\operatorname{LSD}(0.05)$ & 4.324 & 0.041 & 6.0201 & 345.84 & 0.61 & 0.015 \\
\hline CV $(\%)$ & 5.42 & 17.20 & 28.40 & 18.91 & 17.02 & 12.20 \\
\hline F-test & NS & $* *$ & NS & $* *$ & $* *$ & $* *$ \\
\hline \multicolumn{7}{|l|}{ Population density } \\
\hline $88888(75 * 15 \mathrm{~cm})$ & 287.9 & $0.81 \mathrm{~d}$ & $57.6 \mathrm{a}$ & $6961.6 a$ & $14.82 \mathrm{a}$ & $0.47 \mathrm{c}$ \\
\hline $66666(75 * 20 \mathrm{~cm})$ & 288.9 & $0.89 \mathrm{c}$ & $53.3 \mathrm{a}$ & $7182.2 \mathrm{a}$ & $14.94 \mathrm{a}$ & $0.49 \mathrm{ab}$ \\
\hline $53333(75 * 25 \mathrm{~cm})$ & 286.7 & $0.99 b$ & $52.7 \mathrm{a}$ & $7136.7 \mathrm{a}$ & $14.54 \mathrm{a}$ & $0.50 \mathrm{a}$ \\
\hline $44444(75 * 30 \mathrm{~cm})$ & 284.8 & $1.06 \mathrm{a}$ & $46.9 \mathrm{~b}$ & $6542.4 \mathrm{~b}$ & $13.72 b$ & $0.48 b c$ \\
\hline $\operatorname{LSD}(0.05)$ & 3.87 & 0.037 & 5.546 & 309.33 & 0.55 & 0.013 \\
\hline CV (\%) & 6.78 & 19.87 & 33.02 & 19.37 & 18.92 & 13.49 \\
\hline F-test & NS & $* *$ & $* *$ & $* *$ & $* *$ & $* *$ \\
\hline
\end{tabular}

$\mathrm{LSD}=$ Least significant difference; $\mathrm{CV}=$ Coefficient of variation; $\mathrm{NS}=$ Non significant; $\mathrm{EPP}=$ Ears per plant; $\mathrm{HI}=$ Harvest index; $\mathrm{AGB}=\mathrm{Above}$ ground biomass; Values followed by the same letter within a column are not significantly different at $\mathrm{P}<0.05$.

\subsubsection{Aboveground biomass yield}

As regards to the effect of NP fertilizer ratios on the above ground biomass yield the presented data show that the highest above ground biomass yield 15.07 ton $\mathrm{ha}^{-1}$ was recorded by $138 / 104 \mathrm{~N} / \mathrm{P}_{2} \mathrm{O}_{5} \mathrm{~kg} \mathrm{ha}^{-1}$ which was statically at par with $115 / 86 \mathrm{~N} / \mathrm{P}_{2} \mathrm{O}_{5}$ fertilizer rate. On the other hand, the lowest above ground biomass yield 14.70 ton ha ${ }^{-1}$ was obtained from the $69 / 52 \mathrm{~N} / \mathrm{P}_{2} \mathrm{O}_{5}$ fertilizer (Table 2). The above ground biomass yield advantage of $8.0 \%$ was obtained by $115 / 86 \mathrm{~N} / \mathrm{P}_{2} \mathrm{O}_{5}$ as compared to $69 / 52 \mathrm{~N} / \mathrm{P}_{2} \mathrm{O}_{5} \mathrm{~kg} \mathrm{ha}^{-1}$ fertilizer. The result also showed that the above ground biomass increased by increasing NP fertilizer rate application as a result of higher number of ear per plant, plant height and grain yield. Adequate supply of nutrients to the crop helps in the synthesis of carbohydrates, which are required for the formation of protoplasm, thus resulting in higher cell division and cell elongation. Thus an increase in biomass yield might have been on account of overall improvement in the vegetative growth of the plant due to the application of NP fertilizer. Similar results were obtained by Makinde and Ayoola (2010) who reported that conjunctive application of organic and inorganic fertilizers is effective for the growth of maize and improving the yields.

Regarding the effect of plant population density on above ground biomass the obtained results clearly indicate that the highest above ground biomass 19.94 ton $\mathrm{ha}^{-1}$ was recorded from $75^{*} 20 \mathrm{~cm}\left(66,666\right.$ plant ha $\left.^{-1}\right)$ though it was not statistically different from 88,888 and 53,333 plant ha ${ }^{-1}$. While, the lowest above ground biomass 13.72 ton $\mathrm{ha}^{-1}$ was recorded from the lowest plant population density of 44,444 plants ha ${ }^{-1}$ (Table 2). By planting 53,333 plants ha ${ }^{-1}$ there was $6 \%$ above ground biomass increase over plant population density of 44,444 plant ha ${ }^{-1}$. This shows that an increase in plant population density increase above ground biomass yield because the plant per meter square area increase and consequently number of cob harvested. Biomass yield was decreased in wider spacing due to minimum plant height occurred in this treatment due to decreasing the ability of plants for capturing resources which was reflected as evident in their decreased biomass production. These results were in agreement with Bullock et al. (1998) who reported that narrow row spacing made more efficient use of available light and 
shaded the surface soil more completely during the early part of the growing season while the soil is still moist and therefore, narrow row spacing are more effective in producing biomass.

\subsubsection{Harvest index}

The effect of $\mathrm{N} / \mathrm{P}_{2} \mathrm{O}_{5}$ fertilizer rates on harvest index as presented in Table 2 clearly show that numerically, the highest harvest index (0.51) was recorded from application of $138 / 104 \mathrm{~kg} \mathrm{ha}^{-1} \mathrm{~N} / \mathrm{P}_{2} \mathrm{O}_{5}$ fertilizer rate. However, its effect was not significantly different from $92 / 69$ and 115/86 kg ha-1 $\mathrm{N} / \mathrm{P}_{2} \mathrm{O}_{5}$ fertilizer, while the lowest harvest index (0.49) was recorded by lowest fertilizer rate $\left(69 / 52 \mathrm{~kg} \mathrm{ha}^{-1} \mathrm{~N} / \mathrm{P}_{2} \mathrm{O}_{5}\right.$ fertilizer ) (Table 2). As harvest index is the ratio of grain yield to total above ground biomass, thus the highest harvest index was recorded from higher NP fertilizer rate. Adequate supply of NP fertilizer is essential for optimizing partitioning of dry matter between grain and other parts of the maize plant. In addition, optimum utilization of solar radiation, higher assimilates production and its conversion to starch results in higher biomass, grain yield leading to higher harvest index. These findings were in line with results recorded by Kumar and Puri (2001) who observed that the highest harvest index was recorded with $90 \mathrm{~kg} \mathrm{~N} \mathrm{ha}^{-1}$ compared to $45 \mathrm{~kg} \mathrm{~N} \mathrm{ha}^{-1}$ and control.

Concerning the effect of plant density on harvest index , the obtained results show that the highest harvest index (0.50) was recorded from 53,333 plants ha $\mathrm{ha}^{-1}\left(75^{*} 25 \mathrm{~cm}\right)$ although it was not significantly different from 66,666 plants ha $^{-1}\left(75^{*} 20 \mathrm{~cm}\right)$, while the lowest harvest index $(0.47)$ was recorded from 88,888 plants ha $^{-1}$ $\left(75^{*} 15 \mathrm{~cm}\right)$ (Table 2$)$. The harvest index obtained was in the acceptable range of $0.4-0.6$ for maize (Hue, 1995). The result showed that harvest index was decreased by increasing plant density as the result of increasing competition in high densities for the resource. The obtained results were in agreement with the findings of Zamir et al. (2011) and Moraditochaee et al (2012) who claimed that with increasing the plant population, the harvest index was decreased.

\subsection{Economic Analysis}

The open market price $\left(6\right.$ birr kg-1) for maize crop and the official prices of chemical fertilizer $\left(13.5\right.$ birr kg $\left.^{-1}\right)$, urea $\left(10\right.$ birr kg $\left.^{-1}\right)$ and the cost of labor spent on chemical fertilizer application and transport, seed planting and purchase were used for analysis. The cost of application and transport for fertilizer was taken to be 15 birr $100 \mathrm{~kg}^{-1}$. Grain yield was adjusted by $10 \%$ for management difference to reflect the difference between the experimental yield and the yield that farmers could expect from the same treatment (Getachew and Taye, 2005, CIMMYT, 1988).

The dominance analysis procedure as detailed in CIMMYT (1988) was used to select potentially profitable treatments. Dominance analysis led to the selection of treatments ranked in increasing order of total variable costs (Table 3). For each pair of ranked treatments, the percent marginal rate of return (MRR) was calculated. The MRR $(\%)$ between any pair of un-dominated treatments were the return per unit of investment in chemical fertilizer and plant population density. It was calculated by dividing the change in net benefit to the change in variable costs. $100 \%$ MRR means for every 1 birr invested in different cost of fertilizer and maize seed, farmers can expect to recover 1 birr and obtain an additionall birr (CIMMYT, 1988).

Table 3 Partial budget analyses of NP fertilizer rates and plant population density on grain yield of late maturing maize variety at Jimma and Buno-bedele zone during 2016-2018 cropping season

\begin{tabular}{|c|c|c|c|c|c|}
\hline $\begin{array}{l}\mathrm{N} / \mathrm{P}_{2} \mathrm{O}_{5} \\
\left(\mathrm{Kg} \mathrm{ha}^{-1}\right)\end{array}$ & $\begin{array}{l}\text { GY }\left(\mathrm{kg} \mathrm{ha}^{-}\right. \\
\left.{ }^{1}\right)\end{array}$ & $\begin{array}{l}\text { Adj.GY } \\
\left(\mathrm{kg} \mathrm{ha}^{-1}\right)\end{array}$ & $\begin{array}{l}\text { GFB } \\
\left.h^{-1}\right)\end{array}$ & $\begin{array}{ll}\text { TVC } & \text { (ETB } \\
\left.h^{-1}\right) & \\
\end{array}$ & NB $\left(\right.$ ETB ha $\left.^{-1}\right)$ \\
\hline $69 / 52$ & 6636.6 & 5972.9 & 35837.64 & 2933.6 & 32904.04 \\
\hline $92 / 69$ & 7020.7 & 6318.6 & 37911.78 & 3885.3 & 34026.48 \\
\hline $115 / 86$ & 7331.3 & 6598.2 & 39589.02 & 4827.5 & 34761.52 \\
\hline $138 / 104$ & 7566.2 & 6809.6 & 40857.48 & 5807.3 & 35050.18 \\
\hline $\begin{array}{l}\text { NPSZnB }\left(150+140 \mathrm{~kg} \mathrm{ha}^{-1}\right. \\
\text { urea top dressed })\end{array}$ & 6223.9 & 5601.5 & 33609.06 & 3605 & 30004.06 \\
\hline \multicolumn{6}{|l|}{ Plant population density } \\
\hline $88888(75 * 15 \mathrm{~cm})$ & 6961.6 & 6265.4 & 37592.64 & 2216 & 35376.6 \\
\hline $66666(75 * 20 \mathrm{~cm})$ & 7182.2 & 6464.0 & 38783.88 & 1662 & 37121.9 \\
\hline $53333(75 * 25 \mathrm{~cm})$ & 7136.7 & 6423.0 & 38538.18 & 1317.6 & 37220.6 \\
\hline $44444(75 * 30 \mathrm{~cm})$ & 6542.4 & 5888.2 & 35328.96 & 1108 & 34221.0 \\
\hline
\end{tabular}

* GY = Grain yield; GFB = Gross field benefit; $\mathrm{TCV}=$ Total cost that varied; $\mathrm{NB}=$ Net benefit; ETB $=$ Ethiopian Birr; Price of chemical fertilizer $=13.5$ birr kg${ }^{-1}$; Price of Urea $=10$ birr kg-1; Wage rate $=30$ Birr man-day $^{-1}$; Retail price of grain $=6$ birr $\mathrm{kg}^{-1}$.

The data presented in Table 4 and Fig 1 indicate that highest net benefit (35,050.18ETB) was obtained from $138 / 104 \mathrm{~kg} \mathrm{ha}^{-1} \mathrm{~N} / \mathrm{P}_{2} \mathrm{O}_{5}$ fertilizer followed by a net benefit of $(34,761.52 \mathrm{ETB})$ by application of $115 / 86 \mathrm{~kg} \mathrm{ha}^{-1}$ $\mathrm{N} / \mathrm{P}_{2} \mathrm{O}_{5}$ fertilizer with un acceptable MRR(\%) less than $100 \%$ (74.4\% and $98.1 \%$ respectively). Whereas, the lowest net benefit (30,004.06 ETB) was obtained from blended fertilizer application of NPSZnB $150 \mathrm{~kg} \mathrm{ha}^{-1}+140$ $\mathrm{kg} \mathrm{ha}^{-1}$ urea top dressed. The same table also shows that $138 / 104$ and $115 / 86 \mathrm{~kg} \mathrm{ha}^{-1} \mathrm{~N} / \mathrm{P}_{2} \mathrm{O}_{5}$ fertilizer application increased the net benefit by $16.8 \%$ (5046.12 ETB) and 16\% (4757.46 ETB) respectively, as compared with blended 
fertilizer application of NPSZnB $150 \mathrm{~kg} \mathrm{ha}^{-1}+140 \mathrm{~kg} \mathrm{ha}^{-1}$ urea top dressed.

Table 4 Partial budget with dominance analysis and MRR (\%) of NP fertilizer and plant population density of late maturing maize variety at Jimma and Buno-Bedele zone in 2016-2018 cropping season

\begin{tabular}{|c|c|c|c|c|c|c|c|}
\hline $\begin{array}{l}\text { N/P2 } \mathrm{P}_{5} \\
\left(\mathrm{Kg} \mathrm{ha}^{-1}\right)\end{array}$ & $\begin{array}{l}\text { GY } \\
\left(\mathrm{kg} \mathrm{ha}^{-1}\right)\end{array}$ & $\begin{array}{l}\text { Adj.GY } \\
\left(\mathrm{kg} \mathrm{ha}^{-1}\right)\end{array}$ & $\begin{array}{l}\text { GFB } \\
\left(\text { ETB ha-1) }^{-1}\right)\end{array}$ & $\begin{array}{l}\text { TVC } \\
\left(\text { ETB ha-1) }^{-1}\right)\end{array}$ & $\begin{array}{l}\text { NB } \\
\left(\text { ETB ha }^{-1}\right)\end{array}$ & $\begin{array}{l}\text { Domi } \\
\text { nance }\end{array}$ & $\begin{array}{l}\text { MRR } \\
(\%)\end{array}$ \\
\hline $69 / 52$ & 6636.6 & 5972.9 & 35837.64 & 2933.6 & 32904.04 & --- & --- \\
\hline $\begin{array}{l}\text { NPSZnB (150 +140 } \\
\mathrm{kg} \text { ha }^{-1} \text { urea } \\
\text { dressed })\end{array}$ & 6223.9 & 5601.5 & 33609.06 & 3605.0 & 30004.06 & $\mathrm{D}$ & --- \\
\hline $92 / 69$ & 7020.7 & 6318.6 & 37911.78 & 3885.3 & 34026.48 & UD & 117.9 \\
\hline $115 / 86$ & 7331.3 & 6598.2 & 39589.02 & 4827.5 & 34761.52 & UD & 98.1 \\
\hline $138 / 104$ & 7566.2 & 6809.6 & 40857.48 & 5807.3 & 35050.18 & UD & 74.7 \\
\hline \multicolumn{8}{|l|}{ Population Density } \\
\hline $44444(75 * 30 \mathrm{~cm})$ & 6542.4 & 5888.2 & 35328.96 & 1108.0 & 34221.0 & --- & --- \\
\hline $53333(75 * 25 \mathrm{~cm})$ & 7136.7 & 6423.0 & 38538.18 & 1317.6 & 37220.6 & UD & 1431.1 \\
\hline $66666(75 * 20 \mathrm{~cm})$ & 7182.2 & 6464.0 & 38783.88 & 1662.0 & 37121.9 & $\mathrm{D}$ & --- \\
\hline $88888(75 * 15 \mathrm{~cm})$ & 6961.6 & 6265.4 & 37592.64 & 2216.0 & 35376.6 & $\mathrm{D}$ & --- \\
\hline
\end{tabular}

${ }^{*} \mathrm{GY}=$ Grain yield; GFB $=$ Gross field benefit; TCV $=$ Total cost that varied; NB $=$ Net benefit; $\mathrm{D}=$ Dominated treatment; $\mathrm{UD}=\mathrm{Un}$-dominated treatments; $\mathrm{ETB}=$ Ethiopian Birr; Price of chemical fertilizer $=$ 13.5birr kg${ }^{-1}$; Price of Urea $=10$ birr kg-1; Wage rate $=30$ Birr man-day ${ }^{-1}$; Retail price of grain $=6$ birr kg$^{-1}$

Beside, the maximum net benefit $(37,220.6 \mathrm{ETB})$ was obtained from plant population density of 53,333 plant $\mathrm{ha}^{-1}\left(75^{*} 25 \mathrm{~cm}\right)$ with acceptable MRR of $1431.1 \%$ (Table 4$)$. Whereas, the minimum net benefit $(34,221.0$ ETB) was obtained from plant population density of 44,444 plant ha $^{-1}\left(75^{*} 30 \mathrm{~cm}\right)$. Table 4 , also show that the net benefit resulted by plant population of 53,333 plant ha-1 $\left(75^{*} 25 \mathrm{~cm}\right)$, increase by $8.8 \%(2,999.6 \mathrm{ETB})$, when compared with the plant population density of 44,444 plant ha ${ }^{-1}\left(75^{*} 30 \mathrm{~cm}\right)$, the recommended before. The MRR\% was decreased as NP fertilizer rate increased to $138 / 104 \mathrm{~kg} \mathrm{ha}^{-1} \mathrm{~N} / \mathrm{P}_{2} \mathrm{O}_{5}$ and the highest rate of return was recorded from 53,333 plants ha-1 $(75 * 25 \mathrm{~cm})$ (Figure 1$)$.

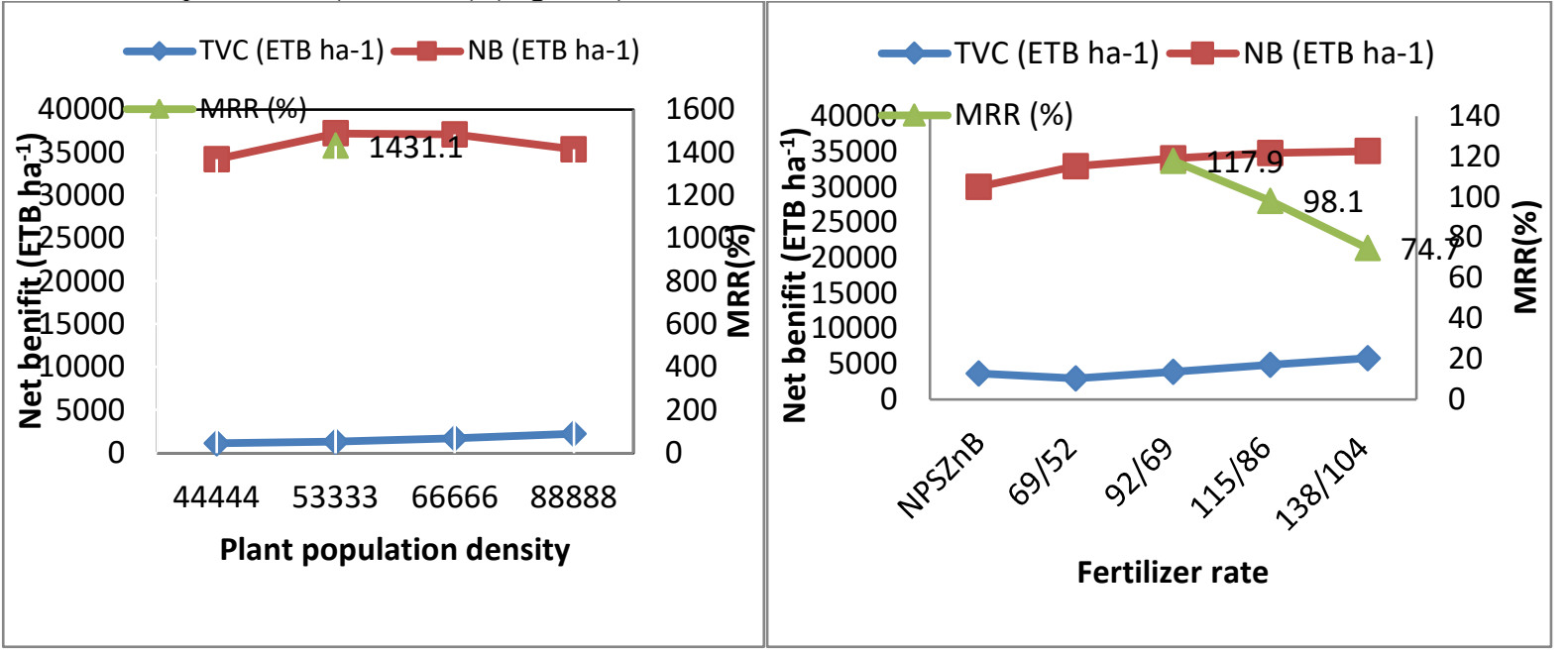

Figure 1 Total variable cost, net benefit and MRR \% of fertilizer rate and plant population density rate of BH661 maize varieties at Jimma and Buno-Bedele zone in 2016-2018 cropping season

It is well known that market prices are ever changing and as such a recalculation of the partial budget using a set of likely future prices i.e., sensitivity analysis, was essential to identify treatments which may likely remain stable and sustain satisfactory returns for farmers despite price fluctuations. The sensitivity analysis study indicates an increase in the field price of the total variable costs, and a fall in the price of maize grain, which represented a price variation of $15 \%$ (Table 5 ).

The price changes are sensitive under market conditions prevailing at Jimma and Buno-Bedele zones which were below the minimum acceptable MRR of $100 \%\left(87.17 \%\right.$ ) for application $92 / 69 \mathrm{~kg} \mathrm{ha}^{-1} \mathrm{~N} / \mathrm{P}_{2} \mathrm{O}_{5}$ fertilizer; whereas the price changes are realistic which were above the minimum acceptable MRR $(1057.78 \%)$ for plant population of 53,333 plant ha $^{-1}(75 * 25 \mathrm{~cm})$ (Table 5). 
Table 5 Sensitivity analysis of maize production based on a $15 \%$ rise in total cost and maize price of gross field benefit fall

\begin{tabular}{|c|c|c|c|c|c|}
\hline $\mathrm{N} / \mathbf{P}_{2} \mathrm{O}_{5}$ Fertilizer & TVC (ETB ha $\left.{ }^{-1}\right)$ & NB $\left(\right.$ ETB ha $\left.{ }^{-1}\right)$ & $\begin{array}{l}\text { Raised } \\
\text { cost }\end{array}$ & Raised benefit & $\operatorname{MRR}(\%)$ \\
\hline $69 / 52$ & 3373.64 & 27968.43 & ---- & ---- & ---- \\
\hline $92 / 69$ & 4468.095 & 28922.51 & 1094.46 & 954.07 & 87.17 \\
\hline \multicolumn{6}{|l|}{ Population density } \\
\hline $44444(75 * 30 \mathrm{~cm})$ & 1274.2 & 29087.8 & ---- & --- & ---- \\
\hline $53333(75 * 25 \mathrm{~cm})$ & 1515.24 & 31637.5 & 241.04 & 2549.68 & 1057.78 \\
\hline
\end{tabular}

\section{Conclusion and Recommendation}

Declining soil fertility aggravated the challenge of agriculture to meet the world's increasing demand for food in a sustainable way and the variations in morphology of the maize crop lead to different planting density to reach at maximum yield. In view of this, the study was conducted to investigate the response of maize hybrid BH661 to different rates of NP fertilizer and plant population density at Jimma and BunoBedele zones, southwestern Ethiopia. Accordingly, rigorous research efforts were made on farmer's fields of Jimma zone(Kersa and Omonada woredas) and Buno-Bedele zone in vicinity of the Jimma research center for three cropping seasons (2016-2018). The results revealed that individual chemical fertilizer and plant population density improved grain yield and above ground biomass yield of the maize. The improvement was mainly due to availability of nutrients from the chemical fertilizer for plant development up to cob formation. The application of chemical fertilizer increased grain yield mainly due to better grain development.

The brief results from across seasons and sites indicate that grain and above ground biomass yield of maize significantly affected by different fertilizer doses and plant population density.

It can be concluded that the maximum grain yield and biomass yield per hectare was recorded with 138/104 $\mathrm{kg} \mathrm{ha}^{-1} \mathrm{~N} / \mathrm{P}_{2} \mathrm{O}_{5}$ fertilizer with highest net benefit of 35,050.18 ETB with MRR 74.7\%. The highest grain yield and biomass yield per hectare was also recorded by plant population density $66,666(75 * 20 \mathrm{~cm})$. However, it was statistically at par with plant population density of 53,333 plant $\mathrm{ha}^{-1}\left(75^{*} 25 \mathrm{~cm}\right)$ which gave the highest net benefit 37,220.6 ETB and MRR 1431.1\%. This result contradicted the previous recommendation of plant population density of 44,444 plant ha $\mathrm{h}^{-1}\left(75^{*} 30 \mathrm{~cm}\right)$. Therefore, plant population density of 53,333 plant ha- $(75 \times 25 \mathrm{~cm}$ a plant hill ${ }^{-1}$ or $75 \times 50 \mathrm{~cm}$ two plants hill $^{-1}$ ) in complement with $\mathrm{N} / \mathrm{P}_{2} \mathrm{O}_{5}$ fertilizer rate of $92 / 69 \mathrm{~kg}^{-1}$ can be recommended in the study area and similar agro-ecologies.

\section{References}

Adeniyan ON, Ojeniyi SO (2005). Effect of poultry manure, NPK 15-15-15 and combination of their reduced levels on maize growth and soil chemical properties. Nigerian Journal of Soil Science 15: 34-41.

Batjes NH (1995). Aglobal data set of soil pH properties. Technical Paper 27, International Soil Reference and Information Centre (ISRIC), Wageningen.

Bavec F, Bavec M (2002). Effect of plant population on leaf area index ,cob characteristics and grain yield of early maturing maize cultivars (FAO 100-400). European journal of Agronomy 16:151-159.

Brady N, Weil RR (2008). Nature and Properties of Soils (14th edn.). Prentice Hall, Upper Saddle River. 992p.

Berhanu D (1980). A survey of studies conducted about soil resources appraisal and evaluation for rural development in Ethiopia, Addis Ababa.70p

Bullock DG, Nielsen RL, Nyquist WE (1988). A growth analysis comparison of corn grown in conventional and equidistant plant spacing. Crop Science 28:254-258.

CIMMYT (1988). From Agronomic Data to Farmer Recommendations: An Economics Training Manual. Completely revised edition. Mexico, D.F.79p

Cox WJ (1996). Whole plant physiology and yield response of maize to plant density. Agronomy Journal 88:489496.

Duncan WG (1984). A Theory to explain the relationship between corn Population and grain yield 1. Crop Science 24(6), 1141-1145.

Farnham DE (2001). Row spacing, plant density and hybrid effects on corn grain yield and moisture. Agronomy Journal 93: 1049-1053.

Getachew A, Taye B (2005). On-farm integrated soil fertility management in wheat on nitisols of central Ethiopian highlands. Ethiopian Journal of Natural Resources 7: 141-155.

Gou L, Huang JJ, Sun R, Ding ZS, Dong ZQ, Zhao M (2010). Variation characteristic of stalk penetration strength of maize with different density-tolerance varieties. Trans. Chinese Society of Agricultural Engineering 26, 
$156-162$.

Hashemi-Dezfouli A, Herbert SJ (1992). Intensifying plant density response of corn with artificial shade. Agronomy Journal 84:547-551.

Hue NV (1995). Sewage sludge. pp.199-247. In: Jack E. Rechcigl (eds). Soil amendments and environmental quality. Lewis Publisher, London.

Karlen DL, Camp CR (1985). Row Spacing, Plant Population, and Water Management Effects on Corn in the Atlantic Coastal Plain 1. Agronomy Journal 77:393-398.

Kumar P, Puri UK (2001). Effect of nitrogen and farmyard manure application on maize varieties. Indian Journal of Agronomy, 46: 255-259.

Lauer J (1994). Should I be planting my corn at a 30-inch row spacing. Wisconsin Crop Manager, Madison 1(6), 311-314

Makinde EA, Ayoola OT (2010). Growth, yield and NPK uptake by maize with complementary organic and inorganic fertilizers, African Journal of Food, Agriculture, Nutrition and Development 10:2203-2217.

McLachlan SM, Tollenaar M, Swanton CJ, Weise SF (1993). Effect of corn-induced shading on dry matter accumulation, distribution, and architecture of redroot pigweed (Amaranthus retroflexus). Weed Science 41:568-573.

Moraditochaee M, Motamed MK, Azarpour E, Khosravi Danesh R (2012). Effects of nitrogen fertilizer and plant density management in corn farming. Asian Research Publishing Network Journal of Agricultural and Biological Science 7: 133-137.

Nivong S, Tasnee A, Russell Y (2007). Nitrogen fertilizer response of maize on some important soils from DSSAT software prediction. Natural Science 41: 21-27.

Porter PM, Hicks DR, Lueschen WE, Ford JH, Warnes DD, Hoverstad TR (1997). Corn response to row width and plant population in the northern Corn Belt. Journal of Production Agriculture 10: 293-300.

Sangoi L, Salvador RJ (1998). Maize susceptibility to drought at flowering: a new approach to overcome the problem. Ciência Rural 28:699-706.

Shah STH, Zamir MSI, Waseem M, Ali A, Tahir M, Khalid WB (2009). Growth and yield response of maize to organic and inorganic sources of nitrogen. Pakistan Journal of life science 7:108-111.

Singh D, Nepalia V (2009). Influence of integrated nutrient management on QPM productivity and soil of South Rajasthan. Indian Journal of Agricultural Science 79: 1020-22.

Song YH, Yukui R, Guta B, Jincai L (2016). Morphological characteristics of maize canopy development as affected by increased plant density. PLoS One 11:e0154084.

Srikanth M, Amanullah MM, Muthukrishnan P (2009). Influence of plant density and fertilizer on yield attributes yield and grain quality of hybrid maize. Madras Agricultural Journal 96(16), 139-143.

Tekalign M, Haque I (1991). Phosphorus status of some Ethiopian soils, II. Forms and distribution of inorganic phosphates and their relation to available phosphorus. Tropical Agriculture 68: 2-8.

Tenaw W, Tesfa B, Tolessa D, Gebeyehu S, Tana T, Geleta N (2002). Development of appropriate cropping system for various maize growing regions of Ethiopia. In: Mandefro N, Tanner D, Twumasi-Afriya S (eds.). Enhancing the contribution of maize to food security in Ethiopia: Proceedings of the second national maize workshop of Ethiopia. 12-16 November 2001, Addis Ababa, Ethiopia. Pp 61 -70.

Tenaw W, Tsegaye H, Tesfa B, Girma W (1993). In: Benti Tolessa and J.K. Ransom (eds.). Proceedings of the First National Maize Workshop of Ethiopia, 5-7 May, 1992. IAR/CIMMYT, Addis Ababa, Ethiopia.

Westgate ME, Forcella F, Reicosky DD, Somsen J (1997). Rapid canopy closure for maize production in the northern US Corn Belt: radiation-use efficiency and grain yield. Field Crops Research Amsterdam 49:249258

Xue J, Gou L, Zhao Y, Yao M, Yao H, Tian J, Zhang W (2016). Effects of light intensity within the canopy on maize lodging. Field Crop Research 188: 133-114.

Yuan ZH, Li YD, Chen HS (2002). Dynamic model and lodging resistance analysis of maize stem. Journal of Maize Science 3: 74-75.

Zamir MSI, Ahmad AH, Javeed HMR, Latif T (2011). Growth and yield behaviour of two maize hybrids (Zea mays L.) towards different plant spacing. Cercetări Agronomice în Moldova 14: 33-40. 